\title{
Locating the fourth helix: Rethinking the role of civil society in developing smart learning cities
}

\author{
Katarzyna Borkowska ${ }^{1}$ - Michael Osborne ${ }^{2}$
}

Published online: 6 June 2018

(C) The Author(s) 2018

\begin{abstract}
In the Global North and increasingly in the Global South, smart city technologies are enthusiastically seen as a solution to urban problems and as an alternative to austerity. However, to move beyond a narrow technological focus, it is necessary to explore the degree to which smart initiatives are committed to building socially inclusive innovation with learning at its core. Using the particular case of the Future City Demonstrator Initiative in Glasgow, United Kingdom, the most high-profile initiative of its kind funded by government, the authors of this article assess the extent to which this smart city adopts such an inclusive approach. They use the quadruple helix model (government - academia - industry - civil society) as a starting point and develop an analytic framework composed of four strands: (1) supporting participation of citizens in decision-making; (2) implementing technological innovation which positions citizens as active users; (3) implementing technological innovation to benefit the community; and (4) evaluating technological innovation in the light of the experiences and needs of citizens. Unlike most analyses, the principal focus of this article is on the fourth element of the helix, civil society. The authors argue that Glasgow's rhetoric of smart urbanism, while aspiring to problem-solving, devalues certain principles of human agency. They emphasise that urban change, including the city's desire to become technologically innovative, would more fully facilitate active citizenship, social inclusion and learning opportunities for all if it were underpinned by the broader conceptions and frameworks of learning cities.
\end{abstract}

Katarzyna Borkowska

katarzyna.borkowska@glasgow.ac.uk

Michael Osborne

michael.osborne@glasgow.ac.uk

1 School of Interdisciplinary Studies, University of Glasgow, Dumfries, UK

2 School of Education, University of Glasgow, Glasgow, UK 
Keywords Quadruple helix model - Smart urbanism - Smart city · Learning city · Future City Demonstrator initiative · Socially inclusive innovation

Résumé Identifier la quatrième pale de l'hélice : repenser le rôle de la société civile dans la création des villes apprenantes intelligentes - Dans l'hémisphère Nord et de plus en plus l'hémisphère Sud, les technologies de ville intelligente sont accueillies avec enthousiasme comme solution aux problèmes urbains et comme alternative aux mesures d'austérité. Néanmoins, pour dépasser une vision technologique étroite, il convient d'explorer dans quelle mesure les initiatives afférentes servent une innovation socialement intégratrice avec la formation en son centre. Prenant le cas particulier du projet de démonstration de la ville du futur à Glasgow (Royaume-Uni de Grande Bretagne et d'Irlande du Nord), initiative phare de ce type financée par le gouvernement, les auteurs de l'article évaluent dans quelle mesure cette ville intelligente adopte une approche inclusive. Ils appliquent le modèle de l'hélice quadruple (gouvernement - milieu universitaire - industrie - société civile) comme point de départ et élaborent un cadre analytique à quatre volets : 1) favoriser la participation des citoyens à la prise de décision; 2) mettre en œuvre une innovation technologique qui positionne les citoyens en utilisateurs actifs; 3) mettre en œuvre une innovation technologique au profit de la collectivité; et 4) évaluer l'innovation technologique à la lumière des expériences et des besoins des citoyens. Contrairement à la majorité des analyses existantes, l'article met l'accent sur la société civile, quatrième élément de l'hélice. Les auteurs avancent que le discours de Glasgow sur l'urbanisme intelligent, même s'il aspire à résoudre les problèmes, dévalorise certains principes de l'action humaine. Ils soulignent que l'évolution urbaine, impliquant le souhait d'une ville innovante sur le plan technologique, faciliterait davantage la citoyenneté active, l'inclusion sociale et les opportunités d'apprentissage pour tous, si elle reposait sur les conceptions et cadres plus vastes de la ville apprenante.

\section{Introduction}

In a rapidly changing and globalised world, cities of the 21 st century are under increasing pressure to develop their technological capacity. Facing a wide range of challenges, including constrained resources, (in-/out-) migration, environmental issues and growing social inequalities (to name a few), cities are searching for smart solutions that are efficient, effective and sustainable (Angelidou 2014; Luque-Ayala et al. 2014).

The concept of smart urbanism (SU) has been in use since the 1990s, initially to describe the use of information and communication technology (ICT) to enhance existing urban infrastructures. In practical terms, this means incorporating technical interventions in a city's core systems such as transport, business, energy, housing, education, environment or communication in order to facilitate optimal resource management and sustainable growth (Hollands 2008; Buck and White 2015; LuqueAyala and Marvin 2015; Albino et al. 2016; Ho 2016). Proponents of this top-down approach to urban development stress the importance of economic competitiveness 
and city branding both within local and global arenas. However, the pressure on cities to become smarter has also attracted considerable criticism. It is argued that smart urbanism creates tensions between the public and private sectors, since smart solutions can be seen to maximise the profits of companies, particularly information technology (IT) giants such as IBM, Cisco Systems, Toshiba, Microsoft and others. Moreover, a technological vision is often a corporate one, and claims of digital transformation may be overstated considering the multitude of challenges faced by cities. Consequently, some researchers (Karvonen and van Heur 2014; Buck and White 2015) question the transformative nature of smart urbanism and its potential to facilitate meaningful change.

For others (Hollands 2008; Luque-Ayala et al. 2014), the smart city ${ }^{1}$ has the potential to dramatically improve local development as long as the vision is not disconnected from citizens and communities. In this view, the human element plays a key role in ensuring that ICT can meaningfully contribute to urban growth. This bottom-up approach, which derives from New Urbanism, ${ }^{2}$ implies that citizens must be involved in developing, promoting and utilising smart solutions (Grant 2005). The integration of smart city interventions into existing urban structures should not neglect the social dimension. Otherwise, SU might lead to further marginalisation of disadvantaged citizens and encourage increased surveillance, as cities pursue their inevitable role as centres of technological innovation (Hollands 2015). The successful and sustainable operation of smart projects depends on the ability of urban citizens to become a part of the smart environment (Luque-Ayala et al. 2014). This reflects the position of the government of the United Kingdom (UK). In a background paper on smart cities, the Department of Business, Innovation and Skills (BIS) stated that citizens should be directly involved in SU developments:

the concept of a Smart City goes way beyond the transactional relationships between citizen and service provider. It is essentially enabling and encouraging the citizen to become a more active and participative member of the community, for example, providing feedback on the quality of services or the state of roads and the built environment, adopting a more sustainable and healthy lifestyle, volunteering for social activities or supporting minority groups (BIS 2013, p. 7).

Rhetoric in support of citizen engagement and mutual exchange to improve lives in communities is common, yet the provision of a learning infrastructure to support these objectives is rare. Such a learning structure should not be a supply-led system offering to "educate" a population, but one that can also promote mutual exchange in the spirit of co-construction of knowledge and expertise, with learning experienced not only by citizens, but also by expert proponents and their organisations. This has been well illustrated by Ilpo Laitinen et al. (2017) in their analysis of the cities of Catania (Italy) and Helsinki (Finland).

\footnotetext{
1 A smart city is a city which implements smart urbanism.

2 New Urbanism promotes the creation and restoration of diverse, walkable, compact, mixed-use, interconnected communities and open spaces to improve the quality of life of citizens.
} 
Smart technologies, in order to empower citizens and improve their quality of life, must facilitate opportunities for mutual learning at individual, community and organisational levels, capturing the potential contributions of all players to a coconstructed future using a smart ecosystem. In a sense, this is merely a new application of the established concept of community of practice ${ }^{3}$ popularised by Etienne Wenger (1998).

Glasgow proclaimed itself a learning city ${ }^{4}$ in 1999 and continues to consider learning a driving force of the city's development (Glasgow City Council 2014). As a learning city, Glasgow is committed to promoting citizen participation, social inclusion and lifelong learning activities for all, and to continuously re-evaluating the learning identity of the city (Jordan and Young 2013). These commitments mirror those of other learning cities around the world, as described in the "Key features of learning cities" developed by UNESCO (UIL 2013). We contend that promoting these features represents a holistic and integrated approach to developing sustainable smart initiatives.

\section{Theoretical background}

The interplay between (1) government, (2) academia and (3) industry in creating knowledge-based economies is captured by the so-called triple helix model of innovation (TH), which was developed by sociologists Henry Etzkowitz and Loet Leyesdorff (1995). Each actor in this triadic relationship contributes according to their established function in society. Governments, for example, being responsible for regulatory frameworks, financing and innovation, control the public sphere. The role of academia/universities is to generate intellectual capital, educating individuals and organisations, and introducing and managing technological and organisational change. Finally, industry is institutionally associated with the production of wealth. Etzkowitz and Leyesdorff further distinguished between three types of TH configuration: a "statist" model; a "laissez-faire" model and a "balanced" triple helix model. ${ }^{5}$ Depending on the type of TH, there may be different degrees of relationship, intersection and synergy among the actors (Etzkowitz and Leydesdorff

\footnotetext{
${ }^{3}$ Community of Practice (CoP) generally refers to a group of people who share a concern about specific topics and meet regularly to collaborate, and to construct and improve knowledge.

4 According to the UNESCO Global Network of Learning Cities, a learning city "is a city which effectively mobilizes its resources in every sector to promote inclusive learning from basic to higher education; revitalize learning in families and communities; facilitate learning for and in the workplace; extend the use of modern learning technologies; enhance quality and excellence in learning; and foster a culture of learning throughout life. In so doing it will create and reinforce individual empowerment and social cohesion, economic and cultural prosperity, and sustainable development" (UNESCO GNLC 2015, p. 9).

5 In a "statist" TH model, the government plays the lead role, driving academia and industry, but also limiting their capacity to initiate and develop innovative transformations. A "laissez-faire" TH model is characterised by a limited state intervention in the economy, with industry as the driving force and the other two spheres (government and academia) acting as supplementary support structures and having limited roles in innovation: university acting mainly as a provider of skilled human capital, and government mainly as a regulator of social and economic mechanisms. A "balanced" TH model is specific to the transition to a Knowledge Society, where university and other knowledge institutions act in
} 
2000). Here, knowledge creation is interdisciplinary, flexible and non-linear, however, still rooted in a top-down approach. The triple helix model extends the earlier "Mode 2" 2 theory of knowledge production characterised by its applied context, transdisciplinarity, its heterogeneity of sites of production (e.g. research centres, government agencies, industrial laboratories, think-tanks) and its reflexivity (Gibbons et al. 1994).

\section{Adding another helix: the quadruple helix model of innovation}

The concept of the knowledge society has been increasingly recognised as a crucial element of technological innovation (Carayannis and Campbell 2006). Consequently, an additional helix, represented by civil society, may be added to government, academia and industry, to highlight the importance of a social dimension in the innovation-generating process. The quadruple helix $(\mathrm{QH})$ model $^{7}$ combines top-down and bottom-up approaches to innovation by recognising that civil society plays an active part in the innovation system. This fourth helix may be a driving force with the capacity to move innovation from a narrow technological focus towards becoming a tool for addressing urban challenges in a sustainable manner. In this article, the focus of our analysis is on the extent to which civil society was involved in the planning, implementation and evaluation of a particular smart city initiative in UK, the Glasgow Future City Demonstrator, and the extent to which this development relates to learning city developments.

Taking into account ownership issues, the overarching goals and the role of users in the process of innovation, Robert Arnkil et al. (2010) distinguished between four different models of QH: (1) the TH + user model; (2) the enterprise-centred living $l a b^{8}$ model; (3) the public-sector-centred living lab QH model; and (4) the citizencentred QH model. The Glasgow Future City Demonstrator initiative, having been created by the UK Government to respond to major urban problems, complies with the third one, the public-sector-centred living lab QH model. The government is the owner of the project and is expected to lead it in collaboration with the other three actor groups. The main objective is to develop efficient and effective public administration products and services for citizens. However, to differentiate it from the TH model, and to combine top-down and bottom-up approaches, the fourth helix must involve socially inclusive innovation.

\footnotetext{
Footnote 5 continued

partnership with industry and government and even take the lead in joint initiatives (Etzkowitz and Leydesdorff 2000).

6 The Mode 2 model in turn is distinguished from the traditional "Mode 1" form of knowledge production, which emanates from academia with a narrow homogeneous disciplinary focus.

7 It should be noted that Elias Carayannis et al. (2012) later introduced a fifth helix representing the environmental settings of a particular region, and hence have referred to their model as the "quintuple helix".

8 A living lab(oratory) integrates research and innovation processes in real-life community contexts to test and promote user-centred, open-innovation ecosystems.
} 


\section{Methodology and framework for analysis}

In order to determine the role of civic society in the technological vision proposed by Glasgow, based on Arnkil et al.'s (2010) public-sector-centred living lab QH model, we derived and established the following indicators of involvement for the purposes of our analysis:

(1) supporting participation of citizens in the process of decision-making (e.g. through traditional methods such as surveys and interviews, with dialogue events including virtual forums, events and living lab environments);

(2) implementing technological innovation which positions citizens as active users;

(3) implementing technological innovation which aims to benefit community in some form; and

(4) evaluating technological innovation in light of the experiences and needs of citizens.

We used these four indicators to evaluate the benefits (if any) of introducing the fourth helix into technological initiatives. Contemporary research on smart urbanism, often preoccupied with the knowledge-based economy, the flow of information and the connectedness of networks, tends to reflect the needs of marketdriven technology companies. The "softer" areas of societal needs and benefits remain largely unexplored (Luque-Ayala and Marvin 2015). The importance of our analysis lies in the acknowledgment that soft factors, such as community engagement and empowerment through learning, have to be accounted for in smart city developments to ensure sustainable outcomes.

We used the set of codes derived from the model by Arnkil et al. (2010) in a deductive a priori fashion as outlined by Benjamin Crabtree and William Miller (1999), and used the six-stage process of coding as described by Jennifer Fereday and Eimear Muir-Cochrane (2006, p. 82) to analyse documentary evidence. We used a single case study approach, as described by Kathleen Eisenhardt (1989) in order to portray the Glasgow Future City Demonstrator, and established our own analytical framework located within Arnkil et al's model of a living lab. Our intent in exploring the single case was to conduct an analysis with depth, as advocated by Gibb Dyer and Alan Wilkins (1991), when they compare the merits of single and multiple case study approaches. The documents we analysed included Glasgow City Council's Future Cities Demonstrator Feasibility Study Final Report (Brown et al. 2012), Arup's Solutions for Cities: An Analysis of the Feasibility Studies from the Future Cities Demonstrator (Arup 2013), and the Technology Strategy Board's Future Cities Demonstrator Competition: Feasibility Studies Interim Report (TSB 2013).

We then looked at how the fourth helix can be used to transform narrow, technologically focused visions into a development akin to that of a learning city, with the far-reaching appeal of wider social benefit. This article claims that the Glasgow initiative did not fully consider or employ methods of civic engagement to ensure an effective use of information technology. While the overarching goal was 
to use smart innovation to address urban challenges related to health, public safety and environmental issues, civic participation was hardly considered in the planning, implementation or evaluation stages of the project. The understanding that a smart city's technological innovations must go hand in hand with empowering citizens and harnessing collective ideas, action and resilience (de Lange and de Waal 2013) is missing in the case we consider. We argue that learning is fundamental to the sustainable development of smart initiatives and can parallel the achievement of some of key objectives of a learning society committed to active citizenship and innovation (Raggett et al. 1995; Osborne et al. 2013).

\section{Glasgow's Future City Demonstrator initiative}

In January 2013, Glasgow (UK) received GBP 24 million in government funding to launch its vision of the future city. Glasgow won a competition against 29 other UK cities to host the Technology Strategy Board's Future Cities Demonstrator. ${ }^{9}$ A government press release stated:

The city will demonstrate how providing new integrated services across health, transport, energy and public safety can improve the local economy and increase the quality of life of Glasgow's citizens, and will allow UK businesses to test new solutions that can be exported around the globe (Gov UK 2013).

This statement indicates that the aim of the initiative was twofold: (1) to promote innovative use of technology to tackle key city challenges; and (2) to position Glasgow (and the UK) on the international stage in terms of technological competitiveness.

Glasgow is the UK's third-largest city (after London and Birmingham) - and Scotland's largest city, with a population of 615,070 in 2016 (NRS 2016). While the cultural aspects of Glasgow are appealing (Glasgow was named the European City of Culture [1990], the UK's City of Architecture and Design [1999], European Capital of Sport [2003], UNESCO City of Music [2008], and hosted the Commonwealth Games [2014]), the city faces a number of problems. Glasgow's Future City Demonstrator initiative identified four main challenges to be tackled through the use of technology. The first was health, as Glasgow has the lowest life expectancy in the UK (female life expectancy is 4.3 years lower than the UK average, while male life expectancy is 6.6 years lower). Public safety is a second major challenge, as Glasgow has a higher level of recorded crime than other Scottish cities. A third recognised challenge is to reduce levels of particulate matter

\footnotetext{
9 The UK government's Technology Strategy Board (TSB), which has supported the development of innovative technologies and products since 2004, was re-labelled Innovate UK in 2014. Its new website is at https:/www.gov.uk/government/organisations/innovate-uk [accessed 10 April 2018]. In 2012, the TSB launched a competition inviting UK cities to bid for a grant to fund a realisation of their vision of how they would integrate their city systems to create better places to live and work. The winning city would thus become a "demonstrator", collecting experience in piloting various innovation projects.
} 
(especially PM10, a harmful air pollutant), while the fourth is to manage the volume of traffic and reduce traffic-related pollution.

Some crucial elements are missing in the challenges identified by the Glasgow City Council. Glasgow is the most socially deprived city and local authority area in Scotland. Based on the Scottish Index of Multiple Deprivation (SIMD 2016), 48 per cent of Glasgow's population live in areas which fall into the bottom 20 per cent of Scotland's most deprived areas (ibid.). Nevertheless, the need to provide skills and jobs for residents was not an imperative identified by the Glasgow City Council as part of the Future City Demonstrator initiative. Glasgow was the only one of the shortlisted cities (the others were London, Bristol and Peterborough) whose bid did not directly refer to local economic growth (Arup 2013). Economic sustainability refers to a city's ability to generate resources and wealth via improved productivity and market competitiveness (Castells 1996). Glasgow City Council (Brown et al. 2012) chose other priorities as the focus of the initiative. The potential to stimulate economic benefits was overlooked in the proposed transformational solutions. However, smart city initiatives, in order to move beyond a narrow technological focus and to be more responsive to the challenges of urbanisation, should aim to contribute directly to the achievement of social benefits.

Glasgow, in its winning bid, chose not to focus on education or community development (Arup 2013). The decision to overlook these aspects of urban change might be explained by the need to conform to the expectations of the Technology Strategy Board. However, as indicated before, the successful and sustainable operation of smart projects depends on urban citizens and their ability to become a part of the smart environment. Changes offered by smart initiatives should be aligned with the development of smart communities. Following the lifelong learning paradigm, the acquisition and transformation of existing knowledge can enable people to adapt and become a part of the changing environment (Laitinen et al. 2017).

Governments, private companies and research funders promote the development and implementation of smart cities as an answer to the challenges of urbanisation. In this context, smart urbanism relates to the desire to transform cities' core systems (such as energy consumption or transport) through integrated technological platforms, creating networks of communication among a variety of urban stakeholders. The fourth helix (civic society) must position itself as a proactive partner in developing and implementing smart technologies. Only then can cities facilitate meaningful knowledge-transfer and build partnerships supporting social, environmental and economic infrastructure. For this reason, the discussion below will focus on an analysis of the fourth helix (via the indicators of involvement) in the context of Glasgow's Future City Demonstrator initiative. Each document was analysed from the perspective of four pre-defined strands derived from Arnkil et al. (2010) described above, each focusing on communities and their experiences. This method of analysis allowed us to conduct an in-depth case study that has wider application for other cities. 


\section{Supporting participation of citizens in the process of decision-making}

Smart city interventions often involve the TH model (government, academia and industry). Glasgow City Council's bid followed this pattern and was co-developed with the University of Strathclyde, an urban design company (IBI Group) and another service provider (ACCESS LLP Group). The latter organisation was founded in 2008 with a 10-year, GBP 265 million contract to improve the Council's ICT and property services. Building on Glasgow's existing resources, which included GBP 500 million in 2014 Commonwealth Games investment, may enhance the TSB's funding outcomes (Buck and White 2015). The smart city solutions proposed by Glasgow fit particularly well with the TSB's technological vision, which focused mainly on transport, energy savings and the environment. At the level of decision-making, Glasgow City Council claims collaboration with over 100 partners in the public, private and academic sectors. However, a consultation with citizens was not part of the development of the smart vision, as evidenced by the Stakeholders Consultation List (Brown et al. 2012, Appendix C).

Robert Hollands (2015) argues that most smart city initiatives follow a corporate vision, which assumes that social and urban development will take place once technological interventions have been implemented. While bidding for the TSB grant, most competing cities sought advice from technical consultancy firms such as Siemens, IBM, Microsoft, Intel, Cisco and Serco. Moreover, Arup (a private-sector consultancy group) was hired by six (of the 29) cities to draft their bids; hence there were commonalities in the cities' technological solutions. Civil society is often seen as a sector that lacks the political power and authority of government and academia, and the economic power of industry. Nevertheless, the rising importance of civic engagement is evidenced in the explosion of activism through social networking websites. For example, during the Arab Spring, social platforms were used to connect and empower individuals to act politically, indicating that civil society had become a major agent for protest, with these platforms performing a catalytic effect (Kamel 2013). That said, the evidence of impact of social media in terms of improving equity and social justice for communities is as yet unclear according to Kevin Harris and Angus McCabe (2017). Nonetheless, it is recognised that without the involvement of local communities, urban challenges cannot be fully addressed (Duke et al. 2013). It is important to make the smart city agenda real for people living and working in cities. Electronic information-handling platforms offered by the Glasgow Future City Demonstrator initiative, while gathering complex information that aimed to benefit the city, largely ignored citizens' involvement, participation and common purpose at the level of decision-making (Brown et al. 2012).

\section{Implementing technological innovation which positions citizens as active users}

Glasgow's vision was to integrate smart technologies into four main service areas: (1) public safety; (2) transport; (3) health; and (4) sustainable energy. The idea was framed by a "Smart City Management System", which consolidates data through 
platforms such as (a) the City Observatory/MyGlasgow Citizen App; (b) City Dashboards (operational management); (c) the Intelligent Operations Centre (handling real-time information and response); and (d) the Data Repository (storing collected data). Through these platforms, data can be accessed and used by a wider community and multiple agencies to deliver responsive city services. In theory, citizens were positioned as active users of technology, but in fact, they were offered few tools to access and benefit from the proposed technological innovations. Several sustainable development theorists (e.g. Gibbs et al. 2013, While et al. 2010) critically examine the politics of urban change in situations where a city desires to become innovative and creative but neglects to develop learning infrastructure.

Citizen engagement opportunities were instituted via the City Observatory platform and included a number of Engagement Hubs across the city (Buchanan Street, Riverside Museum, Mitchell Library, Pollock Civic Realm and the Bridge, Easterhouse). Between September and October 2014, open days were organised to teach citizens how to make life in the city smarter, safer and more sustainable. Similarly, digital literacy programmes ("Future Makers") were run between June and September 2014 to increase the technological competence of children and young people. These actions were based on the understanding that education services provided by local authorities and academia to help citizens gain knowledge, improve skills, adapt to technological changes and apply innovative solutions, has the potential to unlock the potential of sustainable development. For cities to be regarded as truly smart, such interventions must be embedded in long-term frameworks for learning rather than being limited to one-off events. For example, one of the main environmental solutions offered by Glasgow involves auditing data on energy consumption (both in private and public buildings). However, a more robust and socially driven environmental initiative would also include learning related to environmental rights and duties as a key factor in facilitating change. Successful smart cities have the potential to deliver benefits in social, environmental and economic terms - but by their design, which is often generic, abstract and shortterm, initiatives like the TSB's Future City Demonstrator have a high risk of failure (Karvonen and van Heur 2014).

Another issue arising from the implementation of the Future City Demonstrator initiative in relation to positioning citizens as active users of technological innovation is a failure to consider social inequalities in an urban context. In the Feasibly Study Report (Brown et al. 2012, p. 3) and Interim Report (TSB 2013, p. 35), Glasgow City Council indicated that "the people of Glasgow are already technology-literate and keen to be engaged in the further development and use of technology throughout the city". Serious urban problems like poverty and inequality were absent from Glasgow's vision. Technology is presented as widely accessible, yet economic disparities shape the nature of technology use. Lack of basic digital literacy skills, mostly among vulnerable groups, and the high costs of personal computers, smartphones and Internet access can make it difficult for everyone to gain the benefits offered by technology. While implementing the smart vision, there is a need to recognise social inequalities embedded in the urban context and how these shape the experiences of citizens. Failure to consider social inequalities may contribute negatively to social division in cities (Hollands 2015). 


\section{Implementing technological innovation which aims to benefit community (in some form)}

The need to fulfil one of the TSB's main competition criteria - namely, to demonstrate practical application of the investment paired with a short implementation timescale (feasibility study applications developed from June to November 2012, and implementation from January 2013 to August 2014) - resulted in the adoption of a top-down approach to innovation. As indicated above, citizens of Glasgow were not engaged at decision-making levels in creating a vision of smartness. Similarly, they were not empowered to become active users of technological innovations by having learning opportunities provided for them. The top-down rhetoric of smart urbanism was framed to satisfy the requirements of the funder; consequently, the technological visibility of proposed interventions overshadowed the principles of community development, regeneration of neighbourhoods or building community cohesion (Buck and While 2015).

Glasgow's proposed intervention centred on the development of an Integrated Operations Centre, which was created to monitor and control the city's new network of closed-circuit television (CCTV) surveillance cameras, and consequently, improve public safety. Similarly, the installation of Sustainable, Social \& Safe Street Lighting (energy-efficient LED lamps) meant reducing carbon emissions and power consumption while increasing public safety. While there are undeniable benefits for citizens' safety in both cases, it can be argued that their implementation only represents a basic level of innovation; an idea that other cities have already applied without the designation and funding of a smart city.

Nevertheless, technological visibility (prioritised over more traditional forms of community development) was achieved via two electronic citizen engagement app(lication)s. The Active Travel Spatial Analysis app was designed for people who walk and cycle in Glasgow. The app collects information which can be used to improve existing infrastructure, for example cycling paths or parks. The Energy Efficiency in Buildings \& Housing app enables the collection of data on energy consumption in private and public buildings to create a clearer picture of power consumption in the city. It also provides recommendations to homeowners on how to reduce energy consumption.

The Glasgow proposal was framed around the city's social and health priorities, but the implemented solutions had rather limited capacity to address any of these issues. Possibly, more traditional types of investment in community development could have ensured better outcomes. Similarly, attempts to parallel smart urbanism with social interests must be accompanied by a process of promoting and explaining smart solutions to local citizens.

\section{Evaluating technological innovation in light of the experiences and needs of citizens}

According to Chris Duke (2010), the concept of a learning city positions local and regional authorities as facilitators of learning opportunities. Essentially, high-quality learning and widely accessible education and training are seen as a sound 
investment that contributes to economic productivity, competitiveness and social cohesion. A second meaning embedded in the learning city relates to the ability of the city/region to understand, reflect and adapt its provision according to changing needs (i.e. a city that learns). Here, learning is a capacity to collect, analyse and use data to enhance the quality of various interventions.

With an increasing number of smart city initiatives in the UK (and worldwide), it is essential to identify comprehensive methods of evaluating outcomes, to learn from good practice and to identify potential for growth. Glasgow has not yet established (at the time of writing, April 2018) an official evaluation framework for, or formally reported on, the smart city performance. However, evaluation methods must involve knowledge exchange and collaboration between the four helices. Developing rigorous frameworks of evaluation requires negotiation of diverse perspectives and different principles (Duke et al. 2013).

\section{Involvement of the fourth helix in a different Smart City programme: Amsterdam}

While this article is an analysis of a particular smart initiative, it is worth mentioning that similar technological innovations have been implemented in many cities around the world, including Amsterdam, Boston, Chicago, Helsinki, Rio de Janeiro and Stockholm (see, for example, Hielkema and Hongisto 2012; BIS 2013; Lee et al. 2013; Mitchell et al. 2013). At European level, the European Commission (EC 2012) has sought to develop a continent-wide capability by establishing a European Innovation Partnership (EIP) of Smart Cities and Communities.

When we consider these forms of initiative as a whole, they encompass different characteristics and levels of innovation, yet it is increasingly recognised (Riva Sanseverino et al. 2017; Dameri 2017) that in successful technological projects citizens are empowered through the active and democratic contribution and participation in the development, implementation and evaluation of smart initiatives. The city of Amsterdam, for example, is considered an example of successful technological initiative with clear goals and very strong partnership between government, academia, industry and civil society. In 2009, it launched the Amsterdam Smart City Programme, ${ }^{10}$ which addressed, in its initial stage, the problem of pollution, energy consumption and environmental equality in the city. These main areas of interest overlap with the challenges identified in Glasgow.

Unlike the projects envisaged in Glasgow, the smart strategies proposed by Amsterdam heavily rely on active participation of citizens and social bodies in articulating the smart initiatives. Strong cooperation between key stakeholders namely, social bodies/citizens, public bodies, universities/research centres and companies - contribute to creating a regional knowledge network that influences decision-making. Citizens are positioned as active users and are involved in the realisation of the smart initiatives. Out of 36 smart/digital projects, 23 are based on

\footnotetext{
${ }^{10}$ For more information, see https://amsterdamsmartcity.com/network/amsterdam-smart-city [accessed 21 October 2017].
} 
the strong participation of citizens in introducing home technologies (for example, smart energy meters and a neighbourhood car-sharing app) and improving communication between citizens and public bodies. Emancipation through learning is visible through the implementation of seven projects that aim at smart goals without the use of technology. ${ }^{11}$ These projects aim to raise awareness of the concept of a smart city and promote environmentally friendly behaviour. The proposed smart solutions (both with and without technology) are aligned with the cultural profile of the country where attention to environmental issues, digital experience and high democratic values are central components in generating sustainable change (Dameri 2017).

The Amsterdam Smart City Programme positions citizens as the main beneficiaries by aiming to enhance quality of life and economic development. In Amsterdam, quality of life is defined through the prism of environmental quality, digitalisation of public and private services, and availability of public services and facilities (Dameri 2017, p. 134). The higher quality of life attracts young educated people to work in Amsterdam and thus generates economic development. However, the city has to set indicators to measure the impact of smart initiatives on the daily lives of people living and working in the city (Riva Sanseverino et al. 2017).

While Amsterdam appears to have more comprehensively realised smart initiatives than Glasgow (or any other European city), there are still some barriers to achieving a fully inclusive vision. It is significant that the elements of community engagement and empowerment through learning that are absent or minimal in many initiatives have the potential to be strengthened considerably. Amsterdam does offer a number of smart projects based on generating big data sets, but these are not shared or used by the citizens. The city is on a path of building a learning infrastructure that supports the notion of smart initiatives. However, this commitment to build learning opportunities needs to encompass all settings (formal and informal) and be addressed more holistically.

\section{Conclusions}

Glasgow's Future City Demonstrator initiative was ambitious in aiming to tackle health and safety challenges, improve transportation and reduce the environmental impact of the city by integrating multiple systems in a novel manner (for example Energy + Buildings, Transport + Health \& Social Care, Transport + Environment). The installation of 400 CCTV cameras, investment in energy-efficient street lighting and the possibility of reducing $\mathrm{CO}_{2}$ emission through an app are tangible benefits of the Future City Demonstrator. Similarly, the Smart City Management System contributes to increasing transparency of data and public accountability in certain urban functions. Nevertheless, arguably Glasgow's effort to become a city of the future is (to some degree) fragmented and lacks the more holistic grounding of learning city initiatives.

\footnotetext{
${ }^{11}$ For an overview of the projects, see https://amsterdamsmartcity.com/projects [accessed 21 October 2017].
} 
The focus of our in-depth thematic analysis was upon identifying the involvement of the fourth helix in the implemented technological vision. Using the theoretical framework of the quadruple helix, we have concentrated on the involvement of the fourth player, civil society, considering how citizens participated in decision-making, how they were positioned as active users of technological innovation, how communities benefited, and how the initiative was evaluated. We have argued that across each of these four dimensions, there has been limited civil society and citizen involvement. There has been little evidence of involving civil society actors in a truly bottom-up approach, which distinguishes the quadruple from the triple helix (Carayannis and Rakhmatullin 2014, p. 220).

Glasgow's vision connects its citizens, at least theoretically, with technology through an assumption of pervasive digital inclusion and willingness to use smart innovations. Successful and sustainable operation of this type of project is conditioned by urban citizens being a part of the smart learning ecosystem (LuqueAyala et al. 2014). The city developed a number of technological interventions (e.g. smartphone apps and other digital platforms) for use within particular urban infrastructures, but technology in itself does not facilitate active citizenship and public engagement. Furthermore, even if citizens participate and are engaged, this does not guarantee that they will take advantage of smartness. This, we argue, will only happen if learning permeates the helices.

Glasgow's bid did not at its outset address the ecoystemic value of learning infrastructure. Whilst in theory, for the public, a wide range of innovations became accessible to individual citizens and organisations, in practice, these have limited benefits to citizens if not supported through the provision of learning opportunities. It is clear, as has been argued elsewhere (Osborne 2014), that for smart initiatives to be translated into social and economic benefit, there needs to be a focus on learning that pervades everyday life; not only do citizens need to be actively engaged, but they also need means to support the effective use of the new smart technologies if they are to improve the quality of their lives.

The key challenge for many cities seeking to become smart is social inequality. Limited access to the Internet and lack of basic digital literacy, mostly among socioeconomically disadvantaged urban citizens, makes it difficult for them to gain the benefits offered by smart solutions. This is clearly the case in Glasgow. According to the Scottish Household Survey (Scottish Government 2015), at 73 per cent, Glasgow has one of the lowest levels of household Internet access in Scotland. This reflects national trends that associate low household income with low Internet usage. Furthermore, a lower proportion of those in social housing by comparison to those in the private rented sector in Scotland overall report being less confident in digital competency according to a survey by Ipsos MORI (2015), a market research organisation. Similar findings pertain to citizens aged over 60 and those with low incomes in the range of GBP 10,000-GBP 20,000 per annum). Hence the incentive to widen access to technology, particularly in areas of deprivation - of which there are many in Glasgow - may be seen as a sound investment, providing benefits that cross generations, but only if complemented by learning opportunity.

In the case of the Future City Demonstrator initiative in Glasgow, a lack of focus on socially-inclusive economic growth raises questions about the nature of smart 
urbanism and whether it is socially orientated or rather represents the interests of producers of new technologies (see Luque-Ayala et al. 2014; Buck and White 2015). While the city might be seen as a marketplace for technological innovation, investment in these innovations should involve a potential for developing long-term community benefits. Glasgow's biggest challenges relate to social equity and linked outcomes, notably class-related disparities in health and employment in different parts of the city. Possibly, technological solutions have been overstated and have little capacity to deliver significant change. Smart urbanism has to some degree a transformative potential, but technological initiatives should aim to align social, environmental and economic issues. These concepts are often complementary, and neglecting anyone may undermine the impact of proposed initiatives. Technological solutions alone, without investing in infrastructures such as in public housing, and in skills and employment, are unlikely to be successful.

There is a pressing need to establish holistic frameworks for initiatives such as the Future City Demonstrator in Glasgow, frameworks which take into account wider societal interests. Our analysis of smart city developments reveals that the process of technological change could be framed by the fundamental principles of learning city initiatives. The approach of a learning city captures the need to reorient urban contexts by facilitating civic engagement, empowering citizens through lifelong learning, and enhancing a socially inclusive society. These considerations could influence how smart cities are cultivated to ensure a successful and sustainable contribution to development that benefits all citizens. The concept of the learning city has been promoted mainly from the perspective that education and lifelong learning are key to sustainable urban development (Duke 2010). Core factors in the building of learning cities have been issues of social justice and cohesion, and the ability of individuals to participate in decision-making processes. Such participation can help citizens to appreciate the complexities of urban transformation and feel greater ownership of outcomes. Learning city models recognise the importance role of the fourth helix - civil society - adding a participatory dimension which many smart city developments lack, just as was the case in the learning city's predecessor, the "learning region", a model of innovation based on regional development coalitions also formed through the traditional triple helix (Anheim 2012).

Cities work with private sector technology companies (and sometimes academia) in a triple helix to create and implement a vision of smart urbanism. If a fourth dimension constituted by citizens is given a voice to provide their perspectives in all stages of development, this may lead to greater sustainability for the proposed interventions. Moreover, a multiplicity of perspectives increases the number and diversity of solutions, bringing to bear existing knowledge held by communities and recognising that knowledge may be co-created and innovation driven by users. Smart cities might follow the lead of the European Union's Smart Specialisation Platform, ${ }^{12}$ which emphasises the vital role of civil society in translating research into innovation and mutual learning. Whether the vision involves technological

\footnotetext{
${ }^{12}$ For more information on the Smart Specialisation Platform see http://s3platform.jrc.ec.europa.eu [accessed 19 April 2018] and, for an overview, Foray (2015).
} 
innovations or focuses on more conventional interventions, ultimately each city has to identify its own strategies and apply them in its own unique manner, as exemplified by the Amsterdam Smart City Programme, but all beneficiaries must be involved. The shared element of smart urbanism should be that urban growth is based on the idea of enhancing a socially inclusive society (EC 2012) where the notion of sustainability remains paramount.

Open Access This article is distributed under the terms of the Creative Commons Attribution 4.0 International License (http://creativecommons.org/licenses/by/4.0/), which permits unrestricted use, distribution, and reproduction in any medium, provided you give appropriate credit to the original author(s) and the source, provide a link to the Creative Commons license, and indicate if changes were made.

\section{References}

Albino, V., Berardi, U., \& Dangelico, R. M. (2016). Smart cities: Definitions, dimensions, performance, and initiatives. Journal of Urban Technology, 22(1), 3-21.

Angelidou, M. (2014). Smart city policies: A spatial approach. Cities, 41(1), S3-S11.

Anheim, B. (2012). The changing role of learning regions in the globalizing knowledge economy: A theoretical re-examination. Regional Studies, 46(8), 993-1004.

Arnkil, R., Järvensivu, A., Koski, P., \& Piirainen, T. (2010). Exploring quadruple helix: Outlining useroriented innovation models. Työraportteja 85/2010 Working Papers. Tampere: University of Tampere, Institute for Social Research. Retrieved 21 October 2017 from http://uta32kk.lib.helsinki. fi/bitstream/handle/10024/65758/978-951-44-8209-0.pdf? sequence=1.

Arup. (2013). Solutions for cities: An analysis of the feasibility studies from the Future Cities demonstrator programme. London: Arup/Technology Strategy Board.

BIS (Department for Business Innovation and Skills). (2013). Smart cities: Background paper. BIS/13// 1209. London: Department for Business Innovation and Skills. Retrieved 26 February 2018 from https://www.gov.uk/government/uploads/system/uploads/attachment_data/file/246019/bis-13-1209smart-cities-background-paper-digital.pdf.

Brown, R. et al. (2012). Future Cities demonstrator feasibility study: Final report. TSB File Reference No: 130964. Glasgow: Glasgow City Council Development \& Regeneration Services (DRS) and Land \& Environmental Services (LES) in association with the University of Strathclyde, ACCESS and IBI Group.

Buck, N. T., \& White, A. (2015). Competitive urbanism and the limits to smart city innovation: The UK Future Cities initiative. Urban Studies, 54(2), 501-519.

Carayannis, E. G., Barth, T. D., \& Campbell, D. F. J. (2012). The quintuple helix innovation model: global warming as a challenge and driver for innovation. Journal of Innovation and Entrepreneurship, 1(1), 1-12.

Carayannis, E. G., \& Campbell, D. F. J. (2006). "Mode 3": meaning and implications from a knowledge systems perspective. In G. C. Elias \& D. F. J. Campbell (Eds.), Knowledge creation, diffusion, and use in innovation networks and knowledge clusters. A Comparative systems approach across the United States, Europe and Asia (pp. 1-25). Westport, CT: Praeger.

Carayannis, E. G., \& Rakhmatullin, R. (2014). The quadruple/quintuple innovation helixes and smart specialisation strategies for sustainable and inclusive growth in Europe and beyond. Journal of Knowledge Economy, 5(2), 212-239.

Castells, M. (1996). Rise of the network society: The information age. Cambridge: Blackwell.

Crabtree, B., \& Miller, W. (1999). A template approach to text analysis: Developing and using codebooks. In B. Crabtree \& W. Miller (Eds.), Doing qualitative research (pp. 163-177). Newbury Park, CA: Sage.

Dameri, R. P. (2017). Smart city implementation: Creating economic and public value in innovative urban systems. Cham: Springer.

De Lange, M., \& de Waal, M. (2013). Owning the city: New media and citizen engagement in urban design. First Monday, 18(11), Article no. 4954 [online article]. Retrieved 21 October 2017 from http://firstmonday.org/article/view/4954/3786.

Duke, C. (2010). Learning cities and regions. In P. Peterson, E. Baker, \& B. McGaw (Eds.), International encyclopedia of education (pp. 144-149). Oxford: Elsevier. 
Duke, C., Osborne, M., \& Wilson, B. (2013). A new imperative: Regions and higher education in difficult times. Manchester: Manchester University Press.

Dyer, W. G., \& Wilkins, A. L. (1991). Better stories, not better constructs, to generate better theory: A rejoinder to Eisenhardt. The Academy of Management Review, 16(3), 613-619.

EC (European Commission) (2012). (2012). Smart cities and communities: European innovation partnership. C(2012) 4701 final. Brussels: European Commission.

Eisenhardt, K.M. (1989). Building theories from case study research. Academy of Management Review, 14(4), 532-550. Retrieved 21 October 2017 from http://ec.europa.eu/transparency/regdoc/rep/3/ 2012/EN/3-2012-4701-EN-F1-1.PDF.

Etzkowitz, H., \& Leydesdorff, L. (1995). The triple helix-university-industry-government relations: A laboratory for knowledge-based economic development. European Association for the Study of Science and Technology (EASST) Review, 14(1), 14-19.

Etzkowitz, H., \& Leydesdorff, L. (2000). The dynamics of innovation: From national systems and "mode 2" to a triple helix of university-industry-government relations. Research Policy, 29(2), 109-123.

Fereday, J., \& Muir-Cochrane, E. (2006). Demonstrating rigor using thematic analysis: A hybrid approach of inductive and deductive coding and theme development. International Journal of Qualitative Methods, 5(1), 80-92.

Foray, D. (2015). Smart specialisation: Opportunities and challenges for regional innovation policy. London: Routledge.

Gibbons, M., Limoges, C., Nowotny, H., Schwartzman, S., Seot, P., \& Trow, Martin. (1994). The new production of knowledge: The dynamics of science and research in contemporary societies. London: Sage.

Gibbs, D., Krueger, R., \& MacLeod, G. (2013). Grappling with smart city politics in an era of market triumphalism. Urban Studies, 50(11), 2151-2157.

Glasgow City Council. (2014). ASPIR 2014. Education Services annual service plan and improvement report: A learning city. Glasgow: Glasgow City Council. Retrieved 21 October 2017 from https:// www.glasgow.gov.uk/CHttpHandler.ashx?id=31591\&p=0.

Gov UK (Government of the United Kingdom). (2013). 224 million investment will make Glasgow a city of the future [online press release 25 January]. Retrieved 21 October 2017 from https://www.gov.uk/ government/news/24-million-investment-will-make-glasgow-a-city-of-the-future.

Grant, J. (2005). Planning the good community: New urbanism in theory and practice. London: Routledge.

Harris, K. \& McCabe, A. (2017). Community action and social media: A review of the literature. Third Sector Research Centre Working Paper 139. Birmingham: University of Birmingham. Retrieved 19 April 2018 from https://www.birmingham.ac.uk/generic/tsrc/documents/tsrc/working-papers/working-paper-139.pdf.

Hielkema, H., \& Hongisto, P. (2012). Developing the Helsinki smart city: The role of competitions for open data applications. Journal of the Knowledge Economy, 4(2), 190-204.

Ho, E. (2016). Smart subject for a smart nation? Governing (smart)mentalities in Singapore. Urban Studies, 54(13), 1-17.

Hollands, R. G. (2008). Will the real smart city please stand up? City, 12(3), 303-320.

Hollands, R. G. (2015). Critical interventions into the corporate smart city. Cambridge Journal of Regions, Economy and Society, 8(1), 61-77.

Ipsos MORI (2015). Basic digital skills, UK Report 2015. Prepared by Ipsos MORI for Go ON UK, in association with Lloyds Banking Group. London: Ipsos MORI. Retrieved 15 April 2018 from https://s3-eu-west-1.amazonaws.com/digitalbirmingham/resources/Basic-Digital-Skills_UK-Report2015_131015_FINAL.pdf.

Jordan, L., \& Young, S. (2013). Glasgow as a learning city: Towards a renewed vision. [Pascal International Exchanges (PIE) project web post, 28 October]. Retrieved 21 October 2017 from http://pie.pascalobservatory.org/pascalnow/pascal-activities/news/glasgow-learning-city-towardsrenewed-vision.

Kamel, S. H. (2013). Egypt's ongoing uprising and the role of social media: Is there development? Information Technology for Development, 20(1), 78-91.

Karvonen, A., \& van Heur, B. (2014). Urban laboratories: Experiments in reworking cities. International Journal of Urban and Regional Research, 38(2), 379-392.

Laitinen, I., Piazza, R., \& Stenvall, J. (2017). Adaptive learning in smart cities: The cases of Catania and Helsinki. Journal of Adult and Continuing Education, 23(1), 119-137.

Lee, J. H., Phaal, R., \& Lee, S. H. (2013). An integrated service-device-technology roadmap for smart city development. Technological Forecasting and Social Change, 80(2), 286-306. 
Luque-Ayala, A., \& Marvin, S. (2015). Developing a critical understanding of smart urbanism? Urban Studies, 52(12), 2105-2116.

Luque-Ayala, A., McFarlane, C., \& Marvin, S. (2014). Smart urbanism: Cities, grids and alternatives? In M. Hodson \& S. Marvin (Eds.), After sustainable cities? (pp. 74-90). London: Routledge.

Mitchell, S., Villa, N., Stewart-Weeks, M., \& Lang, A. (2013). The internet of everything for cities: Connecting people, process, data, and things to improve the "livability" of cities and communities. San Jose, CA: Cisco Systems Inc. Retrieved 26 February 2018 from http://www.cisco.com/web/ strategy/docs/gov/everything-for-cities.pdf.

NRS (National Records of Scotland). (2016). Glasgow City-Council area profile [online resource]. Retrieved 14 April 2018 from https://www.nrscotland.gov.uk/files//statistics/council-area-datasheets/glasgow-city-council-profile.html.

Osborne, M. (2014). Why lifelong learning and why learning cities? Pedagogy, 86(7), 1067-1077.

Osborne, M., Kearns, P., \& Yang, J. (2013). Learning cities: Developing inclusive, prosperous and sustainable urban communities. International Review of Education, 59(4), 409-423.

Raggett, R., Edwards, R., \& Small, N. (Eds.). (1995). The learning society: Challenges and trends. London: Routledge.

Riva Sanseverino, E., Riva Sanseverino, R., \& Vaccaro, V. (Eds.). (2017). Smart cities atlas western and eastern intelligent communities. Cham: Springer.

Scottish Government. (2015). Scottish household survey 2015. Edinburgh: Scottish Government. Retrieved 15 April 2018 from http://www.gov.scot/Publications/2016/09/7673.

SIMD (Scottish Index of Multiple Deprivation). (2016). Key findings in SIMD16. In SIMD, Scottish index of multiple deprivation 2016 (p. 7). Edinburgh: The Scottish government. Retrieved 14 April 2018 from http://www.gov.scot/Publications/2016/08/6427/7.

TSB (Technology Strategy Board). (2013). Future cities demonstrator competition: Feasibility studies interim report. London: Technology Strategy Board. Retrieved 21 October 2017 from https:// connect.innovateuk.org/documents/3130726/6091879/Future+Cities+Feasibility+Studies++Interim+Report.pdf/4ab345d6-105c-4a88-867f-12e7b976780b.

UIL (UNESCO Institute for Lifelong Learning). (2013). Key features of learning cities. In UNESCO, International conference on learning cities. Lifelong learning for all: Inclusion, prosperity and sustainability in cities (pp. 27-36). Conference report, 21-23 October, Beijing. Hamburg: UNESCO Institute for Lifelong Learning (UIL). Retrieved 26 February 2018 from http://unesdoc.unesco.org/ images/0022/002267/226720e.pdf.

UNESCO GNLC (Global Network of Learning Cities). (2015). UNESCO Global Network of Learning Cities: Guiding documents. Hamburg: UNESCO Institute for Lifelong Learning (UIL). Retrieved 10 April 2018 from http://www.uil.unesco.org/fileadmin/keydocuments/LifelongLearning/learningcities/en-unesco-global-network-of-learning-cities-guiding-documents.pdf.

Wenger, E. (1998). Communities of practice: Learning, meaning, and identity. New York: Cambridge University Press.

While, A., Jonas, A. E. G., \& Gibbs, D. (2010). From sustainable development to carbon control: Ecostate restructuring and the politics of urban regional development. Transactions of the Institute of British Geographers, 35(1), 76-93.

\section{The authors}

Katarzyna Borkowska is a lecturer in Education at the University of Glasgow, School of Interdisciplinary Studies. Her main research interests revolve around social equality, virtual environments and computer-mediated communication. More recently, she has become interested in examining the social and political implications of implementing smart technologies in urban contexts.

Michael Osborne is a professor of Adult and Lifelong Learning at the University of Glasgow and Director of Research within the School of Education. He is experienced in adult and continuing education, vocational education and training (VET) and higher education research, development and evaluation. His current focus is on higher education (HE) and its regional engagement role, learning cities, global challenges and international development. He is also the director of the Centre for Research and Development in Adult and Lifelong Learning (CR\&DALL) and the co-director of the PASCAL Observatory on Place Management, Social capital and Lifelong learning within the School of Education. 